\title{
NATIONAL PARK OF ITI: ENVIRONMENTAL AND GEOMORPHOLOGICAL IMPACTS FROM THE MINING ACTIVITY (GREECE)
}

\author{
Mertzanis A. ${ }^{1}$, Karetsos G. ${ }^{2}$, Smyrni V. ${ }^{3}$, Efthimiou G. ${ }^{4}$, and Zakinthinos G. ${ }^{5}$ \\ ${ }^{1}$ Technological Educational Institute of Lamia, Forestry and Natural Resources Management \\ Department,36100,Karpenisi, Greece,mertzanis@teilam.gr \\ ${ }^{2}$ National Agricultural Research Foundation (NAGREF), Forest Research Institute, 11528 Ilisia, \\ Greece,kage@fria.gr \\ ${ }^{3}$ National and Kapodistrian University of Athens, Faculty of Biology, Department of Botany, \\ Athens, Greece,vsmyrni@biol.uoa.gr \\ ${ }^{4}$ Technological Educational Institute of Larissa, Forestry and Natural Resources Management \\ Department, 34100, Karditsa, Greece, efthimiou@teilar.gr \\ ${ }^{5}$ Technological Educational Institute of Kalamata, Department of Agriculture Products \\ Technology, Lab of Horticulture, 24100, Kalamata, Greece, gzak@teikal.gr
}

\begin{abstract}
Bauxite excavation and the inert material quarries, in the wider region of the "National Park of Iti" in combination with the forest fires, the illegal logging, the grazing and the uncontrollable waste disposal, constituted the most important pressures in it's natural ecosystems. Particularly, bauxite ore exploitation that presented elation during the decade of '70s, was implemented without planning and it caused alterations in the natural environment of the region mainly by the continuous excavations, the foreheads of galleries and the extensive depositions of aggregates materials. As a result, all the above led to the occupation or the deforestation of forests and woodlands, the interruption of natural relief continuity and the change of natural geomorphologic processes. The aim of this work, concerns the determination of the impacts to the environment and more specifically the geomorphes and geomorphological processes, by the bauxite ore exploitation and the quarrying activity, that was developed in the wider region of the "National Park of Iti".
\end{abstract}

Key words: Bauxite mines, Environmental Impacts, Environmental geomorphology.

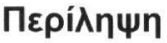

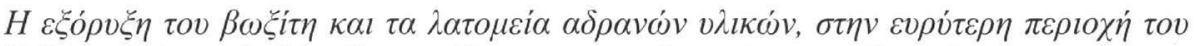

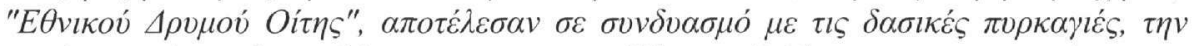

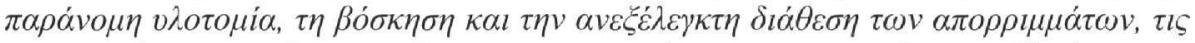

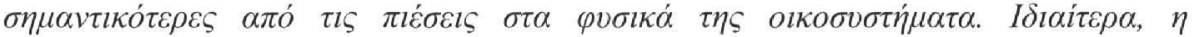

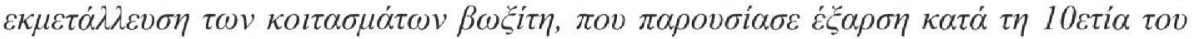

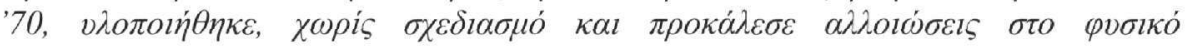




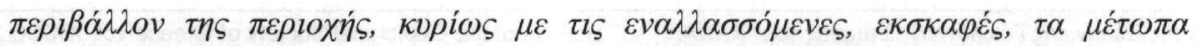

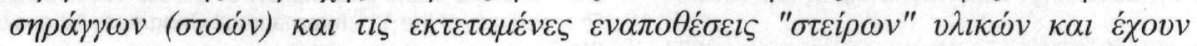

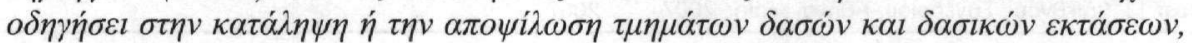

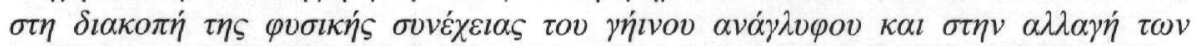

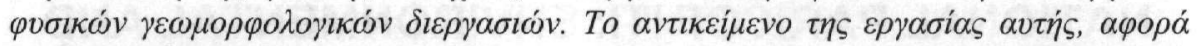

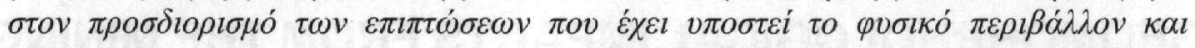

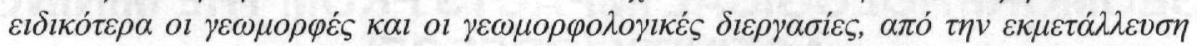

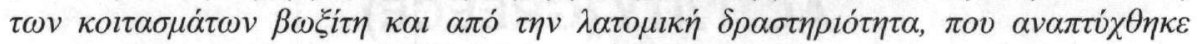

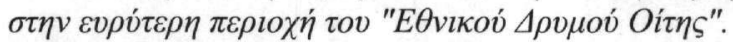

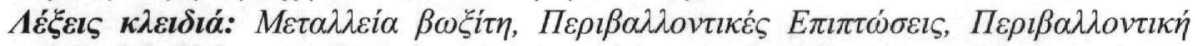

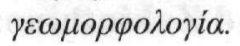

\section{Introduction}

Bauxite ore exploitation in the region of Sterea Hellas (Parnassos - Ghiona), caused serious problems to the natural environment. These problems are connected to the lack of exploitation planning and control by the state. By the course of time these problems became more permanent while at the same time the ideas of ecology and environment protection became familiar to the common opinion. Thus, the state was compelled to apply a stricter legal frame and to impose heavier terms for the exploitation and the obligation for the restoration of the disturbed areas. The companies were forced to incorporate restoration in the planning and the cost of exploitation, with result some of them to abandon the effort. The most solvent of these conceived the new data and were forced to spend money for the restoration and development of research on the object in the Country.

At the region of Mt Iti there is an abandoned mine at the Loukas Kompotadon locality and two in active at Dio Vouna and at the incline of Mexiates locality, respectively. The last one, in the limits of the "National Park" is operating partially. The mining activity, led to the creation of a peculiar environmental unity that occupies parts of forests and woodlands. This unity constitutes of continuous excavations and graduated foreheads of galleries, that are shaped for the access and withdrawal of the ores, and by bulky and extensive depositions of aggregates materials. Also, the dense network of roads for the access to the mines, leads to degradation and strengthens the anthropogenic characteristics of this unit.

Similar pressures to the natural environment of the region, but very limited in extent and dynamics, are caused by the two small quarries, that are located along the road to Pauliani - Pyra and the one in the Kompotades locality that today are out of function.

All the above, in combination with the forest fires, illegal logging and hunting, grazing and uncontrollable waste disposal, constitute one of the most important pressures to the natural ecosystems of Iti (Karetsos et al. 1996).

\section{Materials and Methods}

The environmental status of Mt. Iti was evaluated by using the existing bibliographic data, such as the Management Plan of the "National Park of Iti" (Karetsos et al. 1996), the Special Environmental Study (M.E.P.P.P.W, 2003), the 'Special Management Plan of Sperchios (Georghiou et al. 1996), the NATURA 2000 database (M.E.P.P.P.W. 2003) and the Geographic Information Systems data about the land ecosystems of Central and South Greece (Fasoulas et al. 2001).

For the imprinting of the existing environmental status at the bauxite excavation locations and inert materials quarries, topographical maps, geological maps and maps of vegetation were applied. Also, for the assessment of the pressures and the alterations that the natural environment, particularly the relief, and the natural geomorphologic activities and hydro - geomorphologic 
characteristics that Iti forest ecosystems suffered from the mining activity, photomaps of the Geographic Service of the Army (Hellenic Military Geographical Service), of years 1945, 1960, 1970 and 1986, in scale, 1: 42.000, 1: 30.000, 1: 15.000 and 1:30.000, respectively were used. The interpretation of the photomaps was combined with elements that resulted from the observation on the mining- excavation locations. All these concern the way by which the artificial configuration of cavities or excavations of "pits", the entries of underground withdrawal galleries, as well as elations shaped by the deposition of the aggregates or useless materials were created. For the evaluation, of the pressures' size and the geomorpholocic characteristics alterations, as much as the duration and their reset capability, legislated criteria and indicative sizes are used (Vavizos and Mertzanis 2003).

\subsection{Exisiting status of Iti}

\subsubsection{Institutional frame of the region}

The "National Park of Iti" was established in 1966 by the Royal Decree 218/7-3-1966 "About the foundation of the National Park of Iti " (Official Journal Of The Hellenic Republic 56/12-3-1966 v.A') according to the provisions of the Developmental Law 856/1937. The reasons that led to the declaration of a part of Iti's mountainous massif to a National Park are: a. The impressive topographic configuration of the region and the protection of Abies cephallonica formal forest, $\mathrm{b}$. The connection of Iti with the mythology and the country's history, $c$. The existence of a wild goat species (Rupicapra rupicapra) and $\mathrm{d}$. The existence of impressive meadows and vernal pools at the upper forest zone. In 2003 the Management Authority of the "National Park of Iti" was established and has under it's supervision two more areas that belong to the same mountainous massif: a. The Gorgopotamos Gorge and b. The Asopos Valley (Fig. 1).

The law frame "About the protection of the environment" (L. 1650/1986) incorporates new management principals and is harmonised with the directives and regulations of the European Union. It introduces the obligation of Special Environmental Studies existence and Presidential Decrees passing about the protected areas. It also includes a special chapter "About the protection of Nature and Landscape", that proposes new categories of Protected Areas and introduces changes in the administration and management of protected areas by establishing Management Authorities.

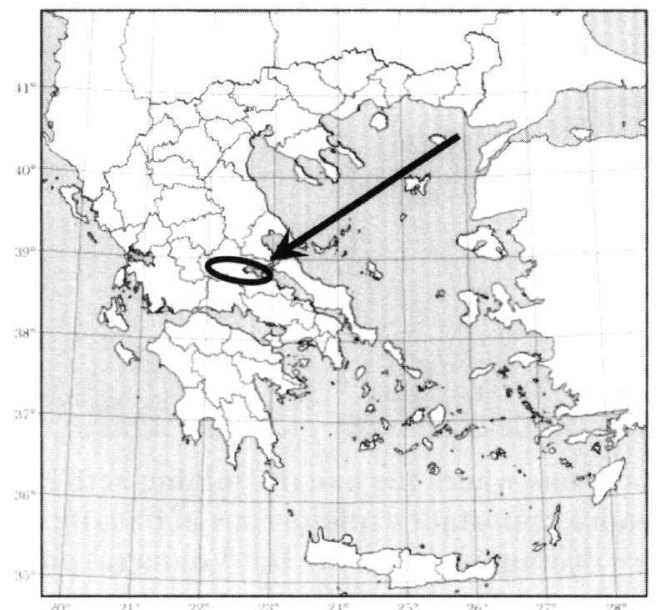

Figure 1 - Geographical location of the area of research

\subsubsection{Geomorphology - Geology}

The relief morphology, in the wider region of the "National Park of Iti", is mountainous with mild to steep slopes and intense morphologic reverses. The dominant structural elements are it's 
limestone steep tops, with highest Pyrgos $(2.150 \mathrm{~m})$ and Greveno $(2.114 \mathrm{~m})$, that are located in the core of the Pak, as well as a line of lower tops, in it's southern part, that approach or exceed 1.500 $\mathrm{m}$ (Tourkos, Xerovouni, Petsalouda tops etc).

The natural sloping and particularly those in the north-northeast side, present strong morphologic inclinations, with deep ravines, that are alternated by round out and intense karstic tops. These forms of relief, are differentiated depending on the nature and location of geological shapings, converting from limestones, that maintain satisfactory mechanic features (inclination $60-85 \%$ ), to flysch, that is characterized by decreased mechanic features and is prone to humification - erosion (inclination 20-60\%) as well as the tertiary terrain depositions. In places on these limestone sloping, at the Dio Vouna and Mexiates localities, the total of bauxite mines is located (Figs 2a, 2b). Northern and north-east, in lower altitudes, quaternary depositions of Sperchios river and it's tributaries, Asopos, Gorgopotamos and Xeria Ypatis, are shaped. These depositions include the alluviums of the valley, the humification - erosion products of the background shapings, the alluvial fan, that constitute dynamically evolving geomorphes and compose in their total, the alluvial extents of the Lamia plain. An important element for the dynamic geomorpholocic evolution of the region, is constituted by the big size alluvial fan (Asopos, Gorgopotamos Xeria Ypatis and Xeria Ano Vardaton) that have been created in the places of hydro graphic systems unloading at the low alluvium area of Sperchios river and that owe their creation in the production of important quantities of brought materials, upwards and in the transport and deposition, downwards, from the hydrographic systems that drain in the wider region of the National Park.

A particular morphologic characteristic is the Gorgopotamos gorge, the crest of which reaches $1500 \mathrm{~m}$. roughly, and it's exit to the plain reaches $50 \mathrm{~m}$, in length of about 6 kilometres. The presence of Katavothra cavern, which is located in the south-west part of Iti, constitutes also a particular morphologic element, while more generally extensive is the presence of karstic cavities and geomorphes of various sizes (dolines, etc), that structure the relief, with characteristics that are impressed particularly intensely in bare by vegetation sloping and the tops, and are results of palaiogeographic evolution of the region, the lithologic constitution of tectonics and climate.
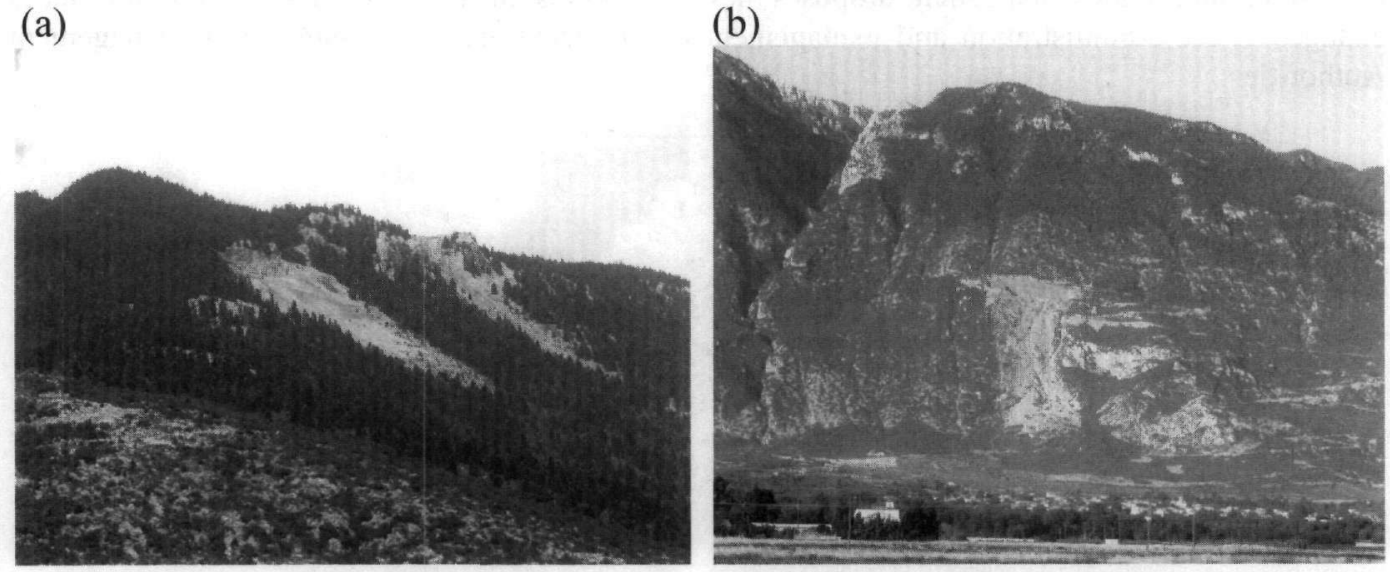

Figure 2 - Aspect of the locations where the bauxite mining activity was developed. With the lightcolor blots, the more important exploitations of bauxite and the depositions of aggregates materials are distinguished, in the Dio Vouna (a) and Mexiates (b) localities

Geologically, the region of research is structured mainly, from sedimentary shapings, that are included geotectonically in the Parnassos- Ghiona and the Sub-Pelagonic series, while in the Koumaritsi locality a small appearance of Peridotite is located. Specifically, regarding to the area Parnassos - Ghiona series, in which the bauxite horizons are located and the mining activities exploitation take place in the wider region of "National Park of Iti", a neritic carbon sequence is constitutes (upper Triassic - upper Cretaceaous) and closes with Flysch (Eocene). This neritic 
sequence, is not continuous, but it is interrupted by a number of bauxite horizons, among which two are mainly used since nowadays for mining exploitation, and have the following characteristics and are defined stratigraphically as follows (I.G.S.R. 1960, I.G.S.R. 1967):

- Upper horizon of bauxite: It concerns red-brownish, tar texture, disperse-dissolutional type layers, rich in aluminium, that are located mainly in the region of research and have been taken advantage to a high degree until today. Stratigraphically they are developed under limestones aged since late Cretaceous with Rudistae limestones on top.

- Lower horizon of bauxite: It concerns red-grayish, tar texture, solutional type layers, of secondary economic importance, in comparison to the superior horizon. Stratigraphically they are developed under limestones aged since early Cretaceous.

\subsubsection{Climate conditions}

The $68 \%$ of annual rainfalls takes place during the humid period and the $32 \%$, the dry period. The height of rainfalls varies from $600 \mathrm{~mm}$, in the low areas to $1800 \mathrm{~mm}$, in the tops of Iti. The rain scale (rain transition every $100 \mathrm{~m}$.), has been assessed at $62,8 \mathrm{~mm}$. The temperature scale is assessed at 0,6 degrees of Celsius respectively. The hottest month is July and the coldest is January. The mean temperature varies from $7,6{ }^{\circ} \mathrm{C}$ the coldest month, up to $27,8{ }^{\circ} \mathrm{C}$ in the lower areas, while at $1800 \mathrm{~m}$ is assessed being ten degrees lower, during the whole year. The dry period lasts 4,5 months in lower areas and one month in the mountainous ones, respectively. Based on UNESCO-FAO (1963) climate classification, the low areas of Iti are included in the weak Thermo-Mediterranean level with mild winter, while the highest areas are included in the Oromediterranean level with harsh winter (Karetsos 2002).

\subsubsection{Vegetation - Flora - Fauna}

The vegetation of Iti consists of evergreen broadleaved formations at lower altitudes, basely shrubs, of deciduous oaks formations at the Koumaritsi - Pauliani localities, of Cephalonian fir forests at the total of the mountainous massif over $600 \mathrm{~m}$. and mountainous meadows in higher altitudes. In this broad distribution, 15 different types of ecotopes are formed, according to the NATURA 2000 recording, 13 of which are included in the Annex I of the Directive 92/43/EEC, while two are new for Greece (Fasoulas et al. 2001). According to recent researches in the wider region of Iti, 10 plant societies and 18 new plant communities exist that were described for the first time (Karetsos 2002).

The areas of the National Park and the Gorgopotamos Gorge are characterized as Sites of Community Interest (SCI), while the area of Asopos Valley is characterized as Special Protection Area (SPA) (M.E.P.P.P.W, 2003, Dimopoulos et al. 2005).

Regarding to the flora, the total number of species that is evaluated as Important for Mt. Iti, based on their integration and protection in National Lists (P.D. 67/81), the Red Data Book of Rare and Threatened Plants of Greece (Phitos et al. 1996) as well as in Threatened Categories according to European and International Lists, reaches 99.

By the 77 endemic species of Mt. Iti, 41 are included in one of the Lists mentioned before. Also $53,2 \%$ of Mt. Iti total endemic species is included in one of the Threatened Categories (Rare, Endangered, Threatened).

In relation to the exclusive endemic species Veronica oetaea, that was located for the first time by Gustavsson (1978), it's biotopes are mentioned to be extremely small in extent. Gustavsson himself reports that it is threatened by the extent of forest road networks and bauxite mining. The second mention does not seem certain because the exploitations are enough distant from the biotopes of the specific species.

Regarding to bird fauna, from the 166 species of birds that are found in the wider region of Iti (Karetsos et al. 1996), 40 of them are considered strictly protected, according to the Community 
Directive 409/79. Half of the protected species (22) use the biotopes that exist in the core and the wider region of the National Park.

The Convention of Bern includes 129 bird species of the wider region, 83 of which are also found inside the Park. It also includes 24 species of mammals, 15 of which are also found inside the Park, mainly bats (chiroptera) and 17 species of amphibians and reptiles. The P.D. 67/1981 strictly protects 35 species of mammals (except for the Wolf and the otter (Lutra lutra), all the rest are chiroptera and 32 species of amphibians and reptiles. Among the birds, a species is characterized as "Threatened" (the lammergeier, Gypaetus barbatus, which however is not a permanent resident of Iti), while 4 species as "Vulnerable" and 5 as "Rare". Among the mammals of the core, 13 species are characterized "Threatened", 5 species "Vulnerable" and 2 species "Rare".

\subsubsection{Water resources (surface and underground waters)}

The bigger part of the wider region of the "National Park", which surface is about 270.147 acres, is draining in the hydrologic basin of Sperchios river (M.E.P.P.P.W. 2003). The main direction of hydrographic network development, that drains at this region (the Asopos, the Gorgopotamos, the Xeria Ypatis and the Xeria Ano Vardates, branches) and discharges in the bed of Sperchios river, is north north-east. These individual hydrographic systems present intense stream action during the rainy months. Also, important part of Iti's mountainous massif (62.562 acres), falls into the basin of the Mornos river and contributes to the homonymous tank (Mornos artificial lake) that supplies Attica with water, while comparatively a small part (6.140 acres), belongs to the Voiotikos Kifisos basin, which flows towards the Copais and the Yliki lakes.

The surface water outflow, at the limestone area, is relatively low, about $40-60 \%$ of the total precipitations, while the hydrographic network that is developed, is of low density in the tops of mountainous elations, because of the intense karstic relief which increases in steep sloping. On the contrary at the area of flysch and the tertiary depositions, the surface water effusion is increased and exceeds in percentage $70-80 \%$ of total precipitations, while the hydrographic network is dense dendritic type.

The percolation in the karstified calcareous volumes, that present the bigger spread in the area of research, is high and reaches $60-80 \%$. For this reason, during the summer period permanent surface flowing waters are absent and are only located downwards the sources of Gorgopotamos river. In the wider region, limestone masses host deep underground aquifer, which in it's bigger part, remains unexploited apart from few drillings of pumping, while significant quantities of water gush from sources (Ypati, Mexiates, Gorgopotamos sources etc). The Quaternary deposits of Sperchios valley, present satisfactory to rich aquifer, particularly in their leachy materials (sandstones, conglomerate, etc), which is supplied directly by the existing hydrographic network.

The chemical constitution of the surface water, at the limestone area, is mainly high in $\mathrm{Ca}^{2+}$ and $\mathrm{HCO}_{3}^{-}$. The concentrations of main cations and anions and $\mathrm{pH}$ are medium to high and this water is characterized as hard, while it's content in heavy metals is low. The $\mathrm{pH}$ of karstic underground water varies from 7 to 8 while it's constitution is proportional to the corresponding surface ones and they are low in mineral (250-500 mg/l)

\subsubsection{Mineral Resources - Excavation Activity}

Bauxite ore is a product of the decay-erosion of Al- rich carbon rocks, with simultaneous washing out of $\mathrm{CaCO}_{3}$, or laterite decay-erosion of igneous rocks, mainly serpentine or even metamorphic rocks.

- Bauxite characteristics: Its mineralogical and chemical composition as well as its physical properties vary. The basic minerals of bauxite are: Boemite, Diasporo, Hidrargilite, all of which constitute the main paragenesis. The main oxides which form bauxite are: $\mathrm{Al}_{2} \mathrm{O}_{3}$, $\mathrm{Fe}_{2} \mathrm{O}_{3}, \mathrm{SiO}_{2}$ and $\mathrm{TiO}_{2}$. The mean chemical composition of higher horizon of the zone Parnassos -Ghiona are: $\mathrm{Al}_{2} \mathrm{O}_{3}(55-65 \%), \mathrm{Fe}_{2} \mathrm{O}_{3}(2-25 \%), \mathrm{SiO}_{2}(1,2-25 \%)$ and $\mathrm{TiO}_{2}(2-2,5 \%)$. 
The following, trace elements have also been found present: $\mathrm{Ga}, \mathrm{Ge}, \mathrm{V}, \mathrm{U}, \mathrm{Th}, \mathrm{La}, \mathrm{Ce}, \mathrm{Zr}$, $\mathrm{Y}, \mathrm{Nb}, \mathrm{Nd}, \mathrm{Ni}, \mathrm{Cr}, \mathrm{Zn}, \mathrm{Pb}, \mathrm{Cu}, \mathrm{Mn}, \mathrm{Sr}, \mathrm{Co}, \mathrm{B}, \mathrm{Be}, \mathrm{Sm}, \mathrm{Au}, \mathrm{Ag}$, and others, out of which the first eight in the list are found in significant concentrations (Papastavrou 1986). More specifically, as far as the elements $\mathrm{Ni}, \mathrm{Cr}, \mathrm{V}, \mathrm{Mn}, \mathrm{Cu}, \mathrm{Ga}$, are concerned, the values in the Greek bauxites range respectively from 81-1.300, 73-2.430, 125-3.100, 25-1.117, 9-76 and 24-102 ppm (Ochenkuhn and Parissakis 1977).

- Methods used for bauxite mining and for aggregates materials quarries exploitation: The main method that has been applied for the excavation of bauxite ores, in the research area, is the underground one (chamber and poles method). Galleries are opened up for the access and excavation of layers and obtaining the ore. In the entries of the underground exploitations (galleries), in certain excavation locations, as in the Dio Vouna and Mexiates locality, vertical or graduated foreheads of excavation have been shaped, up to the surface of the layer, while the aggregates materials are rejected in neighbouring places or are removed. The surface exploitation that shapes vertical or graduated foreheads consistes the main method of exploitation of the three small quarries that are located in the region and that today are out of function. It must be marked out that the environmental legislation (L. 998/79 and L. 1650/86), imposes the environmental restoration of the mining areas, while among the criteria for the choice of the excavation method, increased in gravity criteria are included, related to the protection of the environment.

\subsubsection{Other anthropogenic pressures in the natural environment}

Grazing was practised in the region from ancient years and is continued until today with less intensity. This activity, in combination with fires, sealed the vegetation type of the region, degrading dramatically the type of ancient ecosystems, which form we do not know precisely. The last years, while the fauna has been considerably limited, the erratic cattle-breeding is presented more detrimental to the environment, because it is practised clearly for speculative reasons. This occupation is no more practised by the flocks owners, but from salaried immigrants, who do not know neither are interested for the harmonization with the available food traditional habits of cattle-breeders and existing legal regime. As a result of this situation, the pressures are being continued almost undiminished in the natural environment of the region and the infringements of the existing frame of protection are systematic.

At the same time, the poaching is found in elation and mostly of the wild goat. The poaching is supported by the defective control from the side of the Forest Inspection, the dense road network that has been opened for the cattle-breeders service and also the service of the mining activities. Finally, a serious problem of the region, are the illegal, small or bigger, tips that function without control in various points of Iti. These tips supply, during the floods, the streams with litter, that are transported in bigger recipients (Karetsos et al. 1996).

\section{Results and Discussion}

\subsection{Environmental impacts from the mining-quarrying activity}

The impacts caused by the mining-quarrying activity, mainly concern the occupation of extensive forest and woodlands parts, the vegetation, ground and natural relief destruction, and are combined with the creation of optical changes in the landscape and the nuisances for residents (Brofas 1987). The size, the duration and the possibility of the reset of these changes (impacts), are found in connection with the place and the local parameters of the region environment in each mine functions, as well as with the characteristics of excavation, and specifically from the extent, the place and the volume of excavations and the depositions of aggregates materials (Kaminari et al. 1989, Mertzanis et al. 2005a, Mertzanis et al. 2005b).

For the estimation and evaluation of these environmental changes (impacts) by the manufacture and operation of a work or an activity, all human activities are required to be considered, as well as 
all natural reasons, that cause changes in the environment, that are in place to cause disturbances. A disturbance is defined as each fact or line of facts that cause and influence the structure and the operations of the environment. The transformation of changes in disturbances, depends on the natural, chemical, biological or other type of factors that are also altered by the size of their change, that causes the facts, that influence the environment structure and operations (Vavizos and Mertzanis 2003). The transformation of disturbances in consequences, depends on the environment ability, that suffers the disturbances, to reset them (US-EPA 1997, US-EPA 1999). It is pointed out that the human activities can cause consequences to the environment, not only from emissions of pollutants, but also from their existence only (C.E.C. 1999). The main changes, that have been recorded and are concerned in the region of research, are reported and are:

\subsubsection{Changes in the microclimate}

The changes in the microclimate, are owed to the presence of overdraft surfaces in the limestone foreheads of excavation and to the depositions of aggregates materials, that function as collectors of heat, with result the appearance of high temperatures, particularly at the meridian hours of summer period. The bare from vegetation ground, loses the regulating ability to limit the extreme temperature changes. This phenomenon is attributed also to the fir seedling desiccation, in a neighbouring experimental surface on Mt. Ghiona (Brofas 1989).

\subsubsection{Changes of air quality}

The changes of air quality, are owed to the dust creation and the exhaust emission by the heavy vehicles of mineral and aggregates materials distribution, while they are also resulted by the process of bauxite excavation (excavations, perforations, explosions) and are possible to create problems to the health of workers that are systematically exposed to them (Crounse et al. 1983). These consequences concern mainly the mining activity operation phase, however they are minimized or cancelled at the out of function mines and quarries.

\subsubsection{Changes in the vegetation, the flora and the fauna}

The overlying vegetation destructed by excavations, as well as this of depositions, is more direct to the consequences. At the Dio Vouna locality, big parts of forest have been destroyed and the remainder space, where the mining activity takes place has been fragmentated. The define of forest does not exist any more, as the natural space has been degraded in it's total and no efforts of restoration have been done until today. At the Mexiates locality, because of the steep inclinations, the aggregates materials depositions have occupied, downwards the excavation, enough length leading to the destruction of liable forest shapings.

The region's floristic composition has endured powerful differentiation, resulting to the domination of mainly annual therophyte floristic species at the depositions. However, we consider that the destruction of endemic, rare or threatened species has not happened extensively, because these species are expanded in the total of the mountainous massif and generally in higher altitudes.

As far as the fauna is concerned, there are not any researches of consequences, about Mt Iti. It is considered however that, the infliction during the excavations, the explosions and transport of materials, limit the vital space of birds and mammals and destroy their habitat (Adamakopoulos et al. 1988).

\subsubsection{Alteration of the north and north-east Iti's landscape}

Regarding to the region of research, the landscape alteration from the mining activity, engages particular dimensions, since it is visible from the national road parts as: Thermopiles - Naupaktos (Dio Vouna mines) and Lamia - Karpenisi (Mexiates mines). The exploitation in the Mexjates locality is more visible because of the large inclinations of Iti's north slope and large observation sight. 


\subsubsection{Changes in surface and underground waters}

These changes are represented by the differentiation of natural flow or the water movement direction of the region, their quality and quantity as well as from the changes of the absorption rythm of the surface waters and the draining canals or the rythm and the quantity of the ground washing (Papaspirou et al. 1983, Kaminari et al. 1989, Mertzanis et al. 2004b, Mertzanis et al. 2005a).

\subsubsection{Changes in geomorphologic activities and characteristics of the relief}

The changes that concern the geomorphes and geomorphological processes, and are connected to the development of mining activity, are mainly represented by the disturbance or the interruption of natural continuity of the relief, the changes in the erosion - deposition status of the ground, the creation of unstable ground situations, the change in the geological provision of rock layers as well as the decompositions, shifts, compactions or overlaps of the ground surface layer and the geological shapings. These changes are connected with: a. The artificial configuration of vertical or graduated excavation foreheads, up to the surface of the layer or the entries of galleries, $b$. The artificial configuration of extensive and bulky elations (of big size) from the deposition of aggregates excavation materials, that in certain cases occupy multiple surface size, from the extent of the quarry and c. The opening up of dense road network for the access to the mines (Vavizos and Mertzanis 2003, Mertzanis et al. 2005a, Mertzanis et al. 2005b). More analytically, these changes are:

- Differentiation of physiologic characteristics of water flow out. It is about changes of limited extent, that are owed to the excavation steep inclination, that have been created in the excavation foreheads and in the entries of galleries, as well as in the bare from vegetation ground and result to the increase of quantity and speed of water surface flow out. Locally, in the artificial cavities and the level areas of the quarries, as in the extensive depositions of aggregates materials the opposite phenomenon is observed, that is the increase of the creep in (Papaspirou et al. 1983, Kaminari et al. 1989). Also, a phenomenon that is connected to the deposition of debris and aggregates materials at the torrents watercourse flow that is located in the short length gorge of the contributing sector of Hanorema, at the Dio Vouna locality, as well as at the watercourse of the Gerakari stream (Mexiates mine), is also the restriction or the interruption of normal water flow.

- Increase of ground erosion rythms. The forehead excavations and the spoil of the ground from vegetation, in combination with the dense network of earth-roads manufactured for access, with insufficient technical draining works, new roadway inclinations and oblong mucks, have caused changes in the direction of movement and in the physiologic conditions of surface water flow, that move, upwards the basin parts, according to the hydrolaminar flow and in small scale branches of the hydrographic network. Surface water flow out, is forced to abandon it's normal way, because of roadway condensation and waterproofing, and follows it's inclination or overflow from embanked sloping, with result the amplification of the in-depth gully and retrogressive erosion phenomena (Tsochos 1997). These phenomena, are of limited extent, but are observed in both the localities of bauxite exploitation (Dio Vouna and Mexiates mines).

- Increase of acquired phenomena of territorial fractures and instability, in bare from vegetation sloping of the aggregates materials depositions. The extensive and big height depositions of the aggregates materials that have been created, with increased sloping inclinations (about 80-90\%) and low soil-mechanic characteristics, in combination with the absence of dense vegetation and special protective works, increase the probability of acquired phenomena creation of instability and erosions (Mertzanis et al. 2004a). The conditions are particularly harsh, regarding to the sloping stability, at the depositions of aggregates materials at the main mine of Mexiates, because of the large height of these 
depositions, the main capacity of which exceeds in height $300 \mathrm{~m}$ and their roughly vertical inclinations.

- Increase of the solids content, in the rivers and torrents. The aggregates materials deposition and embanked sloping of the road network for the access to the mines, favor the development of acquired erosion processes and the eclectic transfer of the finer particle-size portions downstream. These products cause increase of solids contents in the aquatic recipients, particularly at the rapid rainfalls duration and are led downwards, through the hydrographic network, where they are layed down, in places where the morphology allows. The result of these processes is the reinforcement, beyond the expected, of the accumulation of sediments in the watercourse of Sperchios river, downwards Mexiates locality, where for the avoidance of floods, deepenings in it's watercourse are held at places, while simultaneously, changes of constitution of cultivated grounds of Lamia plain are not excluded (Adamakopoulos et al. 1988).

\subsubsection{Generation of noise and vibrations}

The generation of noise and vibrations, is owed to rock perforations and the opening up of galleries, the explosions and blowing ups and generally to the works during the bauxite excavation. These impacts concern the mines that are in function.

\section{Conclusions}

The bauxite layers exploitation of the region of research, which today is limited mainly in the locality Dio Vouna, was implented in most cases, and particularly during the decade of '70s, with defective planning. It constituted, in combination with the forest fires, grazing and uncontrollable domestical waste disposal, one of the most important pressures to the natural ecosystems in the region of the "National Park of Iti".

The impacts in the natural ecosystems of the wider region of the "National Park of Iti" and specifically to the disturbance of the relief morphology and the geomorphological processes, and the mining - quarrying activity, are inevitable. The extent, the size, the duration and the reset ability of the impacts to the natural environment, are found in direct relation and are differentiated individually: (a) with the location and the environmental conditions that are developed in the area, in which each mine-quarry is located, (b) with the mining - quarry activity characteristics, that are comprised mainly by the planning that is applied for the mine or quarry development and more specifically from the extent, the place and the volume of depositions of aggregates materials excavations, as well as from the way of their configuration and (c) with the duration of the operation of the mine - quarry, as well as the sufficiency of the applied environmental methods of restoration.

The excavations led to the interruption of the natural relief continuity, while changes were shown to the natural geomorphological processes that were developed in the region. Also, an important impact is the shrinkage of forests, woodlands and grasslands, due to the creation of successive gaps in vegetation, the excavations for the mine layers revelation, the opening up of galleries, the occupation of space because of the aggregates materials deposition, as well as the dense road network of access. This shrinkage of forests and woodlands is connected to the disappearance of multiple operations that were practised by the pre-existing forest parts, that were deforestated for the mines development, most important of which are (multiple operations), the production of timber and secondary products, the change of flora composition and the vanish of certain species from the region, the de-erosioning ground protection and the hydro - economy regulation, the supply of food and shelter to the wild animals and birds, as well as the climatic regulation and aesthetics of the landscape. 


\section{Acknowledgments}

The authors thank, the chairman of the "National Park of Iti" and Mayor of Ypati, Mr. Constantionos Tsilogiannis as well as the Boarding Committee of the Management Authority, for their valuable help, in this research. Also, the PhD student Mrs. Nikoleta Makri for her contribution to the research and translation of the scientific text.

\section{References}

Adamakopoulos, T., Sfikas, G., and Hatzivarsanis, B. 1988. Evaluation and Management of the Ghiona ecosystem. Protection of National forests, pages 94. (in Greek)

Brofas, G., 1987. Investigation for the restoration of land in the quarrying area of Penteli. Study for the restauration of the landscape at the Penteli quarrying site, Forest investigation, 149186. (in Greek)

Brofas, G., 1989. Land restoration in mines, Proc. of the Conference of Geotechnical Chamber of Greece, Athens, 12-13 April. (in Greek)

Castiglioni, G. B., 1997. Geomorfologia, Torino, UTET, 436pp.

C.E.C., 1999. Guidelines for the Assesment of Indirect and Cumulative Impacts as well as Impact Interactions, DGXI.

Crounse, R. G., Pories, W. J., Bray, J.T., and Mauger, R. L., 1983. Geochemistry and Man: Health and Disease, 1. Essential elements. 2. Elements possibly essential, Those toxic and Others, in: Applied Environmental Geochemistry, I. Thorton (ed.), Academic Press, London, 267333pp.

Dimopoulos, P., Bergmeier, E., Theodoropoulos, K., Fischer, P., and Tsiafouli, M., 2005. Monitoring guide for habitat types and plant species in the Natura 2000 sites of Greece with Management Institutions. University of Ioannina and Hellenic Ministry for the Environment, Physical Planning \& Public Works, Agrinio, Greece. 172pp.

Georgiou, K., (Progect Leader), 1996. Specific Management Plan for the Site "Koilada kai ekvoles Sperchiou-Maliakos Kolpos (GR2440002) The Goulandris Natural Museum-Greek Biotope/Wetland Centre \& University of Ayhens. Thermi, 275pp.

Gustavsson, L.-六, 1978. Floristic reports from the high mountains of Sterea Ellas, Greece 2. Bot. Notiser 131, 201-213pp., Stockholm.

I.G.S.R. - Institute of Geology \& Subsurface Research, 1960. Geological map of Greece. Amfissa sheet, 1:50.000.

I.G.S.R. - Institute of Geology \& Subsurface Research, 1967. Geological map of Greece. Lamia sheet, 1:50.000.

Karetsos, G., Lirintzis, G., Albanis, K., 1996. Master plan of the Iti National Park. Athens. (in Greek)

Karetsos, G., 2002. The ecology and vegetation study of Iti mountain, Theses Doctorate. University of Patras.

Kaminari, M., Mertzanis, A., and Konstandinidou, R., 1989. Environmental effects from mining activities in Ghiona Mountain, Proc. of the Conference of Environmental Science and Technology, Mitilini, 4-7 September. (in Greek)

Mertzanis, A., Papadopoulos, A., and Pantera, A., 2004a. Acquired instability effects of the landforms, in artificially modulated banks of excavations and bankfills, along the road Thermopylae-Nafpaktos, in the area between Damasta-Skamnos (Ftiotida-Greece), Proc. of 
the International Conference "Eco-Engineering: The use of vegetation to improve slope stability”, Thessaloniki, 13-17 September.

Mertzanis, A., Papadopoulos, A., and Marabini, F., 2004b. Effects of mining activities of bauxite ores on the hydro-geomorphological characteristics of forest ecosystems of Mountain Ghiona, Proc. of the $4^{\text {th }}$ Hellenic grassland Conference. Hellenic grassland Society, Volos, 10-12 November 2004. (in Greek)

Mertzanis, A., Papadopoulos, A., and Pantera, A., 2005a. The impacts to the environment and the creation of «pseudokarst» landforms, from the bauxite mining activity in the mountain of Ghiona (Central Greece), Proc. of the $14^{\text {th }}$ International Congress of Speleology, AthensKalamos, 21-28 August.

Mertzanis, A., Efthimiou, G., Papadopoulos, A., Papadopoulos, A., and Skotida, A., 2005b. The marble quarrying works in the Penteliko mountain, from the ancient times until today and the environmental impacts (Attica - Greece), Proc. of the $3^{\text {rd }}$ International Symposium "Metallurgy in Southeast Europe from Ancient Times till the End of 19 th Century, Sozopol, Bulgaria 26-30, September 2005.

Ochenkuhn, K.M., and Parissakis, G., 1977. Quantitative Untersuchungen von Bauxiten Zentralgriechenlands mittels atomabsorptions- Spektroskopie and Flammenatomemission, Microchimica acta, I , 447-457.

Papaspirou, D., and Papapetrou, P., 1983. A report aiming at giving information on ways of dealing with the problems between the company "Bauxites of Parnassos" and the county of Kastelia in Fokida, Unpublished report, Athens, I.G.M.E., 6pp.

Papastavrou, S, 1986. Greek Bauxites, Athens, I.G.S.R. edition, 53pp.

P.D. 67/81: Presidential Decree 66, Official Journal Of The Hellenic Republic $23 / 30.1 .1981$.

Phasulas, F., Diamantopoulos, S., Mantzavelas, A., and Malamis, A., 2001. Data base of the G.I.S. layers, of the Central and South Greece terrestrial ecosystems, Study 4. Thessaloniki.

Phitos, D., Strid, A., Snogerup, S., and Greuter, W., 1995. The Red Data Book of Rare and Threatened Plants of Greece, WWF. Athens.

Tsochos, G., 1997. Environmental road constructiont, Thessaloniki, University Studio Press, 270pp. (in Greek)

Ministry of Enviroument, Physical Planning and Public Works, 2003. Special Management Plan, Athens, 248pp.

Ministry of Enviroument, Physical Planning and Public Works, 2003. Data base of the "Natura 2000 " program.

US-EPA., 1997. Terms of Environment, National Service Center for Environmental Publications, US.

US-EPA., 1999. Considering Ecological Processes in Environmental Impact Assessment, National Service Center for Environmental Publications. US.

Vavizos, G., and Mertzanis, A., 2003. Environment - Studies of Environmental Impact, Athens, Papasotiriou, 342pp. (in Greek)

Veresoglou, D., 2002. Ecology, Larisa, Perifereiakes Ekdoseis “ella”, 417pp. (in Greek) 